\title{
Katarzyna Szczerbowska-Prusevicius
}

Katarzyna Szczerbowska-Prusevicius - doktor, adiunkt w Katedrze Filologii Germańskiej UMK. Jej zainteresowania badawcze dotyczą związków literatury z muzyką, w tym szczególnie obszaru określanego przez S. P. Schera jako muzyka werbalna (występowanie w dziele literackim postaci muzyków lub opisów dzieł muzycznych). Opublikowała Musik als Gegenstand romantischer Lyrik (Tönning-Lübeck-Marburg 2005). 


\title{
Sztuka i ideologia Antysemickie cienie w twórczości Ryszarda Wagnera i ich konsekwencje
}

\begin{abstract}
$\mathrm{O}$
sobiście nie znam ani jednego dzieła sztuki, które byłoby całkowicie wolne od ideologicznie wątpliwych implikacji”' ${ }^{\prime}$ W ten sposób Marc Weiner wyraża reprezentowany dziś coraz częściej pogląd, że dzieła sztuki nie można oddzielić od czasu i miejsca, politycznych, społecznych i ekonomicznych uwarunkowań, w jakich powstało. Stwierdzenie to jest jednak o tyle szczególne, że stanowi głos w dyskusji, jaka toczy się wokół twórczości operowej Ryszarda Wagnera. Stanowisko Weinera, postulującego uznanie dzieł Wagnera za sztukę zaangażowaną, propagującą treści jego własnych społeczno-krytycznych i estetyczno-politycznych pism, to więcej niż przyczynek do abstrakcyjnych, filozoficzno-estetycznych rozważań - w przypadku Wagnera prowadzi ono do moralnego dylematu współczesnego odbiorcy, do przyznania, że dzieła te przy całej swojej wartości estetycznej zostały przez ich autora zastosowane do złych celów, do przekazywania w symbolicznej, zaszyfrowanej postaci treści antysemickich.

Tematem niniejszego artykułu są różne rodzaje zastosowania dzieł operowych Wagnera, ze szczególnym uwzględnieniem ich warstwy literackiej. Postaci jednoznacznie zdefiniowane jako Żydzi w operach Wagnera nie występują, antysemicki kontekst tych dzieł widoczny jest jedynie w połączeniu z antysemicką ikonografią XIX wieku² oraz pismami teoretycznymi Wagnera, które zawierają zarówno jego własne poglądy, jak i popularne w tym czasie hasła i obrazy. Pierwsza część mojego artykułu stanowi zatem prezentację antysemickich poglądów Wagnera, które zostaną omówione głównie na przykładzie pamfletu Żydostwo w muzyce. Następnie ukazuję, w jaki sposób sam autor wyzyskuje swoje dzieła do propagowania tych poglądów. Kolejnym krokiem jest omówienie konsekwencji zaprojektowania jego oper jako nośnika ładunku ideologicznego, czyli kolejnego etapu ich wykorzystania, jakim była nazistowska instrumentalizacja. W ostatniej części artykułu zastanawiam się nad możliwością defunkcjonalizacji, tzn. uwolnienia dzieła Wagnera od poprzednich zastosowań
\end{abstract}

1 M. Weiner, Antisemitische Phantasien. Die Musikdramen Richard Wagners, Berlin 2000, s. 14: „Ich persönlich kenne kein einziges Kunstwerk, das vollkommen frei wäre von ideologisch fragwürdigen Implikationen". Tłumaczenia cytatów z języka niemieckiego w całym artykule są moje.

2 Zagadnienie to przedstawia obszernie Marc Weiner w publikacji Antisemitische Phantasien. 
oraz nad szczególnym rodzajem użycia dzieła sztuki w formie zakazu jego wykonywania, występującym w powojennej recepcji Wagnera w Izraelu.

W 1850 roku Ryszard Wagner publikuje anonimowo pierwszą wersję swojego antysemickiego pamfletu pod znamiennym tytułem Żydostwo w muzyce $e^{3}$, który jest pierwszym z pism Wagnera traktujących o rasie żydowskiej. Tekst ten uważany jest za jeden z najbardziej rażących antysemickich tekstów XIX wieku. Powodem powstania „rozprawy” jest, jak podaje Wagner, potrzeba zrozumienia i wytłumaczenia „tego nieświadomego odczucia, które ujawnia się wśród ludu jako najwewnętrzniejsza niechęć do natury żydowskiej”s. Niechęć ta jest rzekomo reakcją instynktowną, jej siła stanowczo przerasta dyktowany przez świadomość nakaz jej zdławienia. Postawy przyjazne, afirmatywne wobec ludności pochodzenia hebrajskiego Wagner określa jako „wymuszone samookłamywanie”, jego głos ma stanowić przyczynek do uwolnienia społeczeństwa niemieckiego od tego etycznego przymusu.

Krytykując i szkalując Żydów w iście zjadliwy sposób, Wagner koncentruje się w swoim piśmie co prawda na rozważaniach dotyczących sztuki, a zwłaszcza muzyki, niemniej jednak porusza też kwestie religijnych, politycznych i społecznych resentymentów w stosunku do Żydów, wskazując na ich różną wartość operacyjną we współczesnym mu dyskursie. Wrogość na tle religijnym Wagner uważa za problem nieistotny ze względu na postępujący rozkład religii chrześcijańskiej, która w związku z tym nie jest już wartością, jaką można by przeciwstawić judaizmowi ${ }^{7}$. Pogląd ten odzwierciedla dokonujące się w XIX wieku przekształcenie antyjudaizmu w antysemityzm, którego pierwszym znaczącym przejawem stał się właśnie omawiany pamflet Wagnera. To właśnie antysemityzm, niechęć na tle rasowym, odróżnia pisma Wagnera od wielu innych tekstów skierowanych przeciw Żydom w tym samym czasie.

Pod względem politycznym Wagner nie widzi powodu do konfliktu z ludnością o semickich korzeniach, popiera nawet utworzenie państwa „jerozolimskiego" ${ }^{\prime}$, choć nie ze szlachetnych pobudek, ale ze względu na możliwość pozbycia się w ten sposób Żydów z państwa niemieckiego. Strefą najbardziej problematyczną jest dla Wagnera pozycja, jaką Żydzi zajmują w społeczeństwie. Podkreśla on, że zbytni liberalizm w stosunku do tej grupy etnicznej doprowadził do jej całkowitej dominacji na gruncie ekonomicznym. Zdaniem Wagnera potęga pieniądza gwarantuje Żydom panowanie nad światem, dlatego krytykuje on popieranie emancypacji Żydów, nawołuje natomiast do zaangażowania się w kwestię „emancypacji od Żydów”: „Żyd jest przy aktualnym stanie rzeczy na tym świecie już bardziej niż wyemancypowany: on panuje, i będzie panowal, dopóki pieniądz pozostanie potęgą, w obliczu której nasze wszystkie zabiegi tracą swoją moc"10.

${ }^{3}$ R. Wagner, Das Judentum in der Musik, [w:] idem, Sämtliche Schriften und Dichtungen, t. 5, Leipzig 1911, S. 66-85.

${ }^{4}$ W.-D. Hartwich, Romantischer Antisemitismus. Von Klopstock bis Richard Wagner, Göttingen 2005, s. 205.

${ }^{5}$ R. Wagner, op. cit., s. 66: „die unbewußte Empfindung, die sich im Volke als innerlichste Abneigung gegen jüdisches Wesen kundgiebt, zu erklären”. Por. też ibidem, s. 67: „bei allem Reden und Schreiben für Judenemanzipation fühlten wir uns bei wirklicher, thätiger Berührung mit Juden von diesen stets unwillkürlich abgestoßen”; , das unwillkürlich Abstoßende, welches die Persönlichkeit und das Wesen der Juden für uns hat“.

${ }^{6}$ Por. ibidem, s. 67: „Zwang [...] jener Selbsttäuschung”.

7 Por. ibidem, s. 66.

8 Ibidem, s. 67.

9 Ibidem, s. 68: „Emanzipirung von den Juden".

10 Ibidem: „Der Jude ist nach dem gegenwärtigen Stande der Dinge dieser Welt wirklich bereits mehr als emanzipirt: er herrscht, und wird so lange herrschen, als das Geld die Macht bleibt, vor welcher all' unser Thun und Treiben seine Kraft verliert". 
Swoje właściwe rozważania na temat „natury żydowskiej” Wagner rozpoczyna od uwag dotyczących wyglądu Żydów, odróżniających się od reszty społeczeństwa jako „coś dla [danej] narodowości nieprzyjemnie obcego" ${ }^{11}$. Żydzi są tak brzydcy, że nie powinni być przedstawiani w sztuce, nie mogą też na scenie teatralnej występować w roli bohaterów czy zakochanych, ponieważ budziłoby to śmieszność ${ }^{12}$. Istotny w tych absurdalnych dywagacjach jest fakt, że Wagner określa wygląd, a w dalszej części pamfletu też usposobienie Żydów jako zbiór cech gatunkowych, zakodowanych genetycznie. Wyraźnie występuje tu zbliżenie do pojęcia „rasy”, które dopiero niebawem stanie się popularne pod wpływem Szkiców o nierówności ras ludzkich Arthura de Gobineau ${ }^{13}$. Takie podejście sprawia, że tekst Wagnera zyskuje protorasistowski status i z tego powodu zajmuje wśród wielu innych krążących wówczas antysemickich pamfletów pozycję szczególną ${ }^{14}$.

Kolejny zespół cech fizycznych, który Wagner przypisuje Żydom, związany jest z językiem. Język narodowości, w której Żyd przebywa, jest dla niego zawsze językiem obcym: „mówi on nim zawsze jak cudzoziemiec” ${ }^{15}$. Konsekwencją złego opanowania języka jest niezdolność do wyrażania się w nim, co ma szczególne znaczenie w dziedzinie sztuki. Żyd może z powodu językowej ułomności jedynie naśladować i powtarzać, a nie tworzyć naprawdę ${ }^{16}$. Za rzecz odrażającą Wagner uważa „czysto zmysłową manifestację"17 języka hebrajskiego. Uważa, że semicka wymowa charakteryzuje się szczególnymi właściwościami, które są wyrazem „nadzwyczajnej uporczywości wrodzonego usposobienia żydowskiego” ${ }^{18}$. W żydowskim sposobie artykulacji Wagner konstatuje „syczący, ostry, brzęczący i mruczący”19 dźwięk. Do tego dochodzą błędne pod względem semantycznym użycia słów, ich przekręcanie i dziwne zestawianie fraz. Powstaje z tego „niezwykle pomieszana paplanina" ${ }^{\text {. }}$. Mowa Żydów charakteryzuje się też obojętnością, niezdolnością do namiętnych uniesień: „zimna obojętność tego osobliwego bełkotu nigdy nie wzniesie się do podniecenia wyższej, rozżarzonej sercem namiętności”"21. Zdaniem Wagnera Żyd nie jest zdolny do wyrażania uczuć, dotyczy to nie tylko języka mówionego, ale jeszcze w większym stopniu śpiewu, który Wagner definiuje jako język namiętności ${ }^{22}$. W śpiewie szczególnie wychodzi na jaw „odrażająca rozwaga żydowskiej natury"23.

Mimo podejmowanych przez Żydów uporczywych prób pozbycia się cech semickich przez wykształcenie i przyjęcie chrztu, są one tak głęboko zakorzenione, że nie można ich zlikwidować. Niepowodzenie procesu asymilacji jest w świetle pisma Wagnera uwarunkowane fizjologicznie. W kilku miejscach artykułu podkreśla on, że Żydzi nie mają

11 Ibidem, s. 69: „etwas dieser Nationalität unangenehm Fremdartiges".

12 Por. ibidem, s. 69 i 70.

${ }^{13}$ W późniejszych pismach, po zapoznaniu się z teorią Gobineau, Wagner również posługuje się pojęciem rasy.

${ }_{14}$ Por. J. M. Fischer, Richard Wagners "Das Judentum in der Musik", [w:] Richard Wagner und die Juden, red. D. Borchmeyer, A. Maayani, S. Vill, Stuttgart-Weimar 2000, s. 38.

${ }^{15}$ R. Wagner, op. cit., s. 70: „er spricht sie immer als Ausländer".

${ }^{16}$ Por. ibidem, s. 71.

17 Ibidem: "die rein sinnliche Kundgebung der jüdischen Sprache".

18 Ibidem: „die sonderliche Hartnäckigkeit des jüdischen Naturells".

19 Ibidem: „ein zischender, schrillender, summsender und murksender Lautausdruck“.

20 Ibidem: „unerträglich verwirrte[s] Geplapper [...]”.

21 Ibidem: "die kalte Gleichgültigkeit des eigenthümlichen 'Gelabbers' in ihr steigert sich bei keiner Veranlassung zur Erregtheit höherer, herzdurchglüheter Leidenschaft".

22 Por. ibidem, s. 72.

23 Ibidem: „widerliche Besonnenheit der jüdischen Natur”. 
własnej tradycji artystycznej, korzystają więc z aryjskich wzorów, ale czynią to nieumiejętnie, przejmują elementy powierzchowne, pomijają to, co istotne, mieszają style i formy ${ }^{24}$. W dziedzinie muzyki taka twórcza niemoc charakteryzuje rzekomo kompozytorów Feliksa Mendelssohna Bartholdiego i Giacomo Meyerbeera ${ }^{25}$, którym Wagner w dalszej części artykułu nie szczędzi słów krytyki i pogardy.

Mimo genetycznej niezdolności do działań artystycznych, Żydom udało się zaistnieć w dziedzinie sztuki. Ich sukces jest dowodem degeneracji sztuki europejskiej, „niezdolności naszej muzycznej epoki artystycznej”26. W okresie, kiedy sztuka europejska była zdrowa, było to niemożliwe.

Ostatni ustęp artykułu Wagnera, dotyczący pisarza Carla Ludwiga Börnego, stanowi jego najbardziej dyskutowaną częśćc ${ }^{7}$. Börne podjął wysiłek pozbycia się swego żydowskiego usposobienia, co mu się udało, ale nie dostąpił „zbawienia”. Nie dostąpił go, ponieważ „zbawienie” oznacza przemianę wszystkich w „prawdziwych ludzi”, co jeszcze nie nastąpiło. Proces ten wymaga zarówno od Żydów, jak i nie-Żydów gotowości do bólu i cierpienia. Do tego miejsca wydaje się, że Wagner mimo przekonania o niższości rasy żydowskiej dostrzega możliwość jej zrównania z resztą społeczeństwa za cenę wielkich wyrzeczeń. Wątpliwości budzi jednak końcowy apel pamfletu, w którym pojawia się wyraźny podział na żydowskie „wy” i nieżydowskie „my”: „Bierzcie bezwzględnie udział w tym przez samozniszczenie odradzającym dziele zbawienia, wtedy będziemy zgodni i nie będziemy się różnić! Ale zważcie, że tylko jedno może być waszym zbawieniem od ciążącego na was przekleństwa: zbawienie Ahasvera - zagłada!"28.

Z jednej strony „samozniszczenie” można uznać za element „dzieła zbawienia”, wtedy dotyczy ono wszystkich ludzi („będziemy zgodni i nie będziemy się różnić!”), z drugiej strony Wagner widzi dla Żydów tylko jedną możliwość „zbawienia” - zagładę („waszym zbawieniem - zagłada"). Na pytanie o to, czy Wagner pojmuje zagładę w sensie dosłownym czy metaforycznym, nie ma jednoznacznej odpowiedzi.

Tak zwane Regenerationsschriften ${ }^{29}$ (Pisma regeneracyjne) uzupełniają antysemickie poglądy Wagnera o ideę aryjskiego chrześcijaństwa. W trzeciej części swojego artykułu Publiczność i popularność Wagner stwierdza, że chrześcijaństwo jest religią zanieczyszczoną żydowskimi elementami, Chrystus natomiast jest pochodzenia aryjskiego, a nie żydowskiego: „Wywodzenie Boga naszego Zbawiciela $\mathrm{z}$ drzewa genealogicznego Izraela jest jednym z najstraszniejszych zagmatwań historii świata" ${ }^{\prime 3}$. Uwaga na ten temat pojawia się również

24 Por. ibidem, s. 75-78.

25 Por. ibidem, s. 79-82. Krytyka tych kompozytorów jest uwarunkowana osobistą zawiścią Wagnera, który z niepokojem śledzi sukcesy konkurentów i boleje nad własnymi niepowodzeniami w tym czasie.

26 Ibidem, s. 83: „Unfähigkeit unserer musikalischen Kunstepoche”.

27 Jens Malte Fischer uważa, że nie ma w tym zakończeniu mowy o fizycznej zagładzie Żydów i że „samozniszczenie" odnosi się zarówno do Żydów, jak i nie-Żydów (J. M. Fischer, op. cit., s. 37). Udo Bermbach reprezentuje pogląd, że Żydostwo $w$ muzyce, w przeciwieństwie do późniejszych pism Wagnera, nie zawiera elementów rasistowskich, a krytyka Wagnera dotyczy jedynie „historycznie nabytych form zachowania”, końcowa zagłada oznacza zatem w jego przekonaniu rewolucyjną przemianę postawy społecznej. (W.-D. Hartwich, Zusammenfassung der Diskussion, [w:] Richard Wagner und die Juden, s. 53).

28 R. Wagner, op. cit., s. 85.

29 Pisma te zostały opublikowane w latach 1877-1881, należą do nich: Was ist deutsch?, Modern, Publikum und Popularität, Wollen wir hoffen?, Religion und Kunst, Erkenne dich selbst, Heldentum und Christentum.

30 R. Wagner, Publikum und Popularität, [w:] idem, Sämtliche Schriften und Dichtungen, t. 10, Leipzig 1911, s. 86: „Daß der Gott unsres Heilandes uns aus dem Stammgotte Israels erklärt werden sollte, ist eine der schrecklichsten Verwirrungen der Weltgeschichte". Ideę aryjskiego chrześcijaństwa głosił jako jeden z pierwszych J. G. Fichte. W latach 70. XIX w. Paul de Lagarde wysunął tezę, że ojcem Jezusa był żołnierz rzymski o imieniu 
w pamiętniku Cosimy: „potem Wagner zapalczywie kwestionuje pogląd, że Jezus był Żydem, nie zostało to udowodnione, mówił on po syrochaldejsku" ${ }^{31}$. Teoria ta powraca w piśmie Religia i sztuka, uzupełniona o przekonanie, że to judaizm doprowadził do upadku chrześcijaństwa: „Nam za to wystarczy wskazanie na wykorzystywanie elementów żydowskich do kształtowania dogmatów jako przyczyny zepsucia religii chrześcijańskiej”32.

Moim zdaniem dzieła operowe Wagnera są nośnikiem ideologii zawartej w jego pismach teoretycznych. W jakim stopniu antysemickie przekonania Wagnera wpisane są w jego opery, przedstawię na trzech najbardziej pod tym kątem dyskutowanych przykładach (Śpiewacy norymberscy, Pierścień Nibelunga, Parsifal).

W operze Śpiewacy norymberscy Wagner ożywia renesansową tradycję pochodzących z kręgów rzemieślniczych poetów-śpiewaków. Punktem kulminacyjnym akcji są zawody śpiewacze, w których bierze udział dwóch diametralnie się od siebie różniących kandydatów. Jednym z nich jest Walther von Stolzing, rycerz. Jego szlachetnemu pochodzeniu odpowiada szlachectwo duszy i talentu. Walther, który nie przeszedł przez żadne stopnie wymagane w hierarchii „Meistersingerów”, reprezentuje kreatywny geniusz, ujawniający się samorodnie, $\mathrm{w}$ chwilach boskiego natchnienia. Nikt z tych, którzy mozolnie wspinają się po stopniach ustalonej przez cech hierarchii, nie potrafi mu dorównać, znajomość zasad tzw. formy barowej, wymaganej w pieśniach, oraz niezliczonych nazw tonów okazuje się bezwartościową i suchą wiedzą w porównaniu z artystycznym zachwytem Walthera. Jego pieśni to zatem według pamfletu Żydostwo w muzyce mowa namiętności, którą władają jedynie Aryjczycy. Sztuka Walthera nie od razu znajduje poparcie cechowych mistrzów - osobowości dość przeciętnych; jedynym, który natychmiast dostrzega wielkość Walthera, jest Hans Sachs. Kontrkandydatem Walthera jest natomiast Sixtus Beckmesser, który najpierw miał nosić nazwisko Hanslich, jako aluzja do znienawidzonego przez Wagnera krytyka żydowskiego pochodzenia, Eduarda Hanslicka. Beckmesser reprezentuje sobą wszystkie cechy przypisywane Żydom w pamflecie Żydostwo w muzyce. Jest jadowity i zazdrosny, od pierwszej chwili nienawidzi Walthera i żywi też niechęć do Hansa Sachsa, ale skrzętnie ukrywa swoje prawdziwe uczucia. Jest pedantyczny, skrupulatnie zapisuje w czasie pierwszego występu Walthera wszystkie odstępstwa od zasad. W swoim sądzie o Waltherze Beckmesserze kieruje się małostkowym egoizmem i zazdrością, pragnie wyeliminować Walthera nie tylko jako śpiewaka, ale też jako rywala w zabiegach o Ewę Pogner. Beckmesser kalkuluje chłodno i z matematyczną dokładnością, Ewa, Walther i Hans Sachs kierują się w swoich sądach uczuciem. Scena, kiedy Beckmesser prosi Sachsa o ocenę pieśni, którą zamierza przedstawić na konkursie, zawiera szczególnie wyraźne odniesienia do wyrażonej przez Wagnera w pamflecie Żydostwo $w$ muzyce krytyki śpiewu żydowskiego. Wykonanie Beckmessera charakteryzuje niecierpliwość i powierzchowność: Beckmesser

Panthera. Teza ta opierała się na starych tekstach żydowskich, w których pojawiało się określenie „Jezus ben Panthera", Jezus syn Panthery. W tekstach tych słowo Panthera wynikało z pomyłki, zostało mylnie użyte zamiast greckiego słowa parthenos, dziewica (P. L. Rose, Richard Wagner und der Antisemitismus, Zürich-München 1999, s. 220). Wynikający z tej pomyłki pogląd wyrażał też Hitler: „człowieczy ojciec Jezusa był [...] rzymskim legionistą" („,der menschliche Vater Jesu sei [...] ein römischer Legionär gewesen”, P. L. Rose, op. cit., s. 221).

${ }^{31}$ C. Wagner, Die Tagebücher 1869-1883, t. 2, München 1976, s. 242: „dann eifert er [Wagner] dagegen, daß Jesus ein Jude war, es sei nicht erwiesen, er habe syrochaldäisch gesprochen“.

32 R. Wagner, Religion und Kunst, [w:] idem, Sämtliche Schriften und Dichtungen, t. 10, s. 232: „Uns wird es dagegen genügen, den Verderb der christlichen Religion von der Herbeiziehung des Judentums zur Ausbildung ihrer Dogmen herzuleiten". 
„brzdąka niecierpliwie na lutni” ${ }^{33}$, „skrzecząc”34, „brzdąka w największej wściekłości” ${ }^{35}$, „Beckmesser $[\ldots]$ był zmuszony $[. .$.$] wydawać często dźwięk [... ] w sposób krótki i gwał-$ towny, co bardzo podkreślało komizm jego wykonania"36. W końcu Beckmesser kradnie pieśn będącą dziełem Walthera, dowodząc tym ostatecznie swej niezdolności twórczej. Próbuje on zapamiętać tekst i melodię cudzego utworu, ale sprawia mu to taką trudność, że zrozpaczony wyciera sobie pot z czoła. Nie może zrozumieć skradzionej pieśni, mimo że pilnie ją studiuje. Zajmując podczas zawodów miejsce do śpiewania, potyka się, kroczy niepewnie, zatacza się. Jego postawa wywołuje ubolewanie widzów i uszczypliwe uwagi. Beckmesser różni się od Walthera nie tylko potencjałem duchowym, ale też wyglądem zewnętrznym. Jego nieudolność staje się oczywista, gdy Walther, w swej „błyszczącej zbroi”, śpiewa tę samą pieśń - ta w jego wykonaniu brzmi pięknie i zachwyca słuchaczy. W postaci Beckmessera odnajdujemy zatem dokładnie te cechy psychiczne i fizyczne, które Wagner w przywoływanym pamflecie określa jako żydowskie. Rozpaczliwe wysiłki Beckmessera stanowią próbę przekroczenia granic jego własnych możliwości.

W Śpiewakach norymberskich pojawia się też ideologia czystej krwi. Połączenie Walthera i Ewy gwarantuje zachowanie czystości rasy, co uwydatnione zostaje przez kontrastujący obraz zalotów Beckmessera, który jako jedyny nie widzi, jak bardzo nie pasuje do pięknej i szlachetnej Ewy. Średniowieczna, kontynuowana przez Meistersingerów forma canzony staje się w operze Wagnera metaforą rasowej czystości: „Stollen”, który łączy się w pieśni z drugim „Stollen”, wykazującym takie same właściwości rytmiczno-metryczne, stanowią według Hansa Sachsa coś na kształt dobrze dobranej pary małżonków. Kończący pieśń „Abgesang” jest jak dziecko, które swoją doskonałością potwierdza doskonałość doboru pary.

Pierścień Nibelunga jest złożoną parabolą polityczną, którą Wagner konstruuje z wybranych opowieści mitologii germańskiej. Postaciami wykazującymi cechy określone przez autora jako żydowskie są tam przede wszystkim Alberich i Mime. Alberich kradnie „złoto Renu” i wytapia z niego pierścień, rzekomo dający jego właścicielowi nieograniczoną władzę nad światem. Formowanie pierścienia z naturalnego tworzywa, jakim było złoto strzeżone przez córki Renu, symbolizuje proces cywilizacji i produkcji - przemianę dóbr natury w towar o wartości użytkowej. Alberich bez trudu spełnia też warunek związany z posiadaniem pierścienia: wyrzeka się miłości. Opętany chęcią zysku karzeł tyranizuje swoich współbraci Nibelungów, zmuszając ich do niewolniczej pracy. Kradzież „złota Renu" uruchamia w cyklu operowym łańcuch zła, w który wciągnięty zostaje także Wotan, władca bogów. On również naznaczony jest żądzą władzy i posiadania, reprezentuje zatem państwo skorumpowane i uzależnione od żydowskich bankierów. Wotan, ogarnięty chęcią zademonstrowania swej potęgi, buduje potężny zamek, Walhall, wikła się jednak w umowę z wykonawcami budowli, olbrzymami Fasoltem i Fafnerem, której nie jest w stanie dotrzymać37. Konsekwencją zawarcia tej umowy jest konieczność zdobycia pierścienia obiecanego olbrzymom jako zapłata za ich usługi. Wotan przemocą odbiera pierścień Alberichowi

\footnotetext{
${ }^{33}$ R. Wagner, Die Meistersinger von Nürnberg, Stuttgart 1958, s. 55: „klimpert voll Ungeduld auf der Laute“.

${ }^{34}$ Ibidem, s. 59: „kreischend".

35 Ibidem, s. 60: "klimpert in höchster Wut".

36 Ibidem, s. 63: „Beckmesser [...] war genötigt [...], oft den Ton [...] kurz und heftig auszustoßen, was das Komische seines Vortrages sehr vermehrte".

37 Pierwszą formą zapłaty miała być bogini Freya. Oddanie Frei olbrzymom oznaczałby jednak dla pozostałych bogów utratę nieśmiertelności, której źródłem były pielęgnowane przez Freyę złote jabłka. Obiecując Freyę olbrzymom, Wotan musiał zatem planować, że tego przyrzeczenia nie dotrzyma. W krytycznym momencie olbrzymi zabierają Freyę, ale zgadzają się ją uwolnić w zamian za złoto Renu.
} 


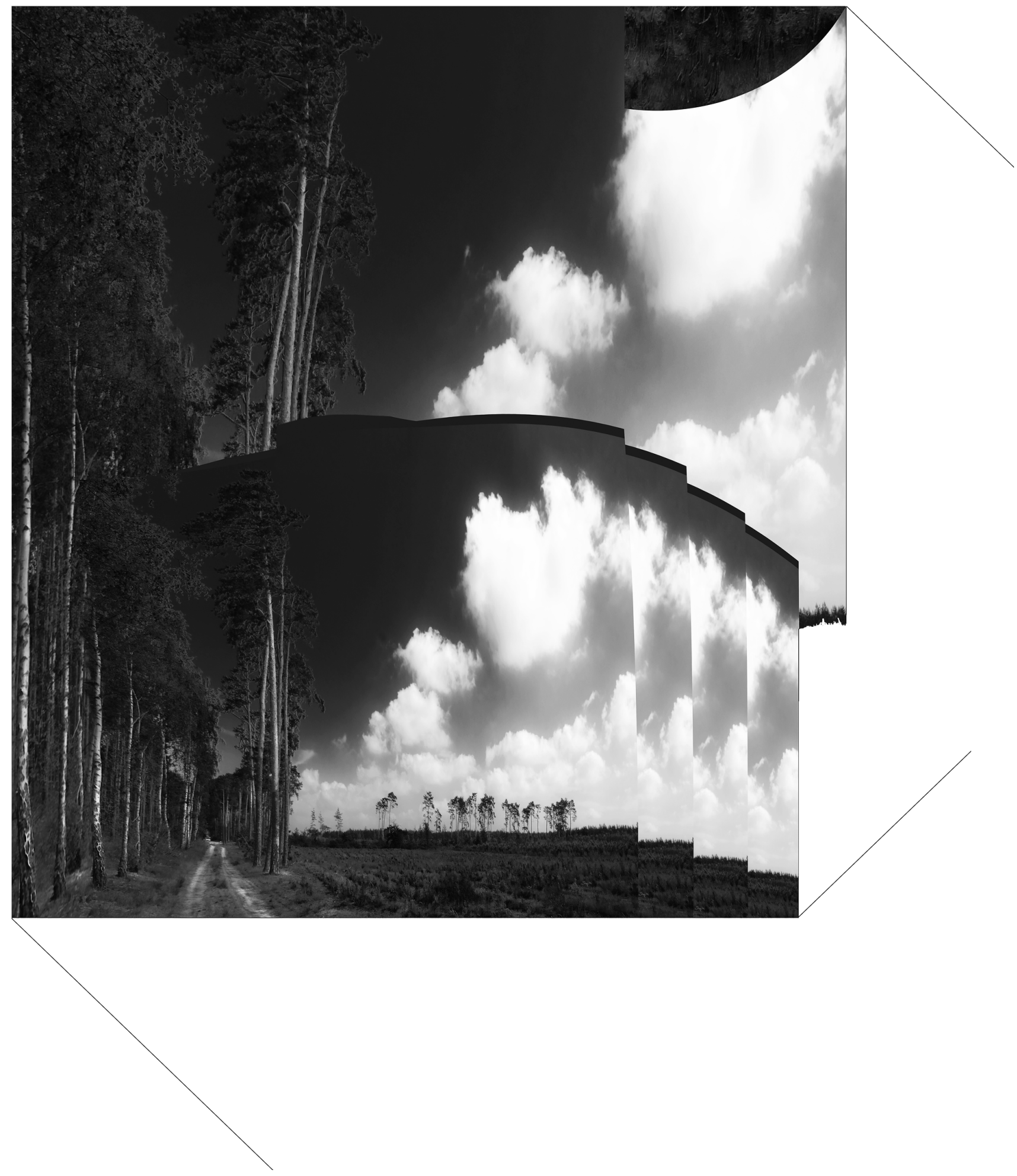

Przestrzeń - 001 
(w ten sposób władca bogów postępuje tak samo jak wstrętny karzel) i, choć niechętnie, przekazuje go olbrzymom. Po zabiciu Fasolta, Fafner jest władcą pierścienia i świata. Jako smok, który „leży i posiada”38, symbolizuje burżuazyjne społeczeństwo, delektujące się swoim bogactwem. Wotan, który sam związał sobie ręce, nie jest w stanie mu tej władzy odebrać. Czynu tego dokonać może jedynie Zygfryd, wolny bohater, postępujący niezależnie od woli Wotana. Zwycięża on smoka i zdobywa pierścień, pada jednak ofiarą intrygi Albericha, który dąży do odzyskania pierścienia, ciosem w plecy zabija go syn Albericha Hagen. Jego śmierć nie jest jednak nadaremna, Brunhilda, ukochana córka Wotana i zdradzona narzeczona Zygfryda, oddaje pierścień córkom Renu, sama natomiast ginie w płomieniach żałobnego stosu Zygfryda, łącząc się z nim na wieki. Jej poświęcenie okazuje się zbawienne dla świata, zaklęty przez Brunhildę ogień niszczy zamek Walhall wraz ze skorumpowanymi bogami, a wody Renu obmywają pogorzelisko, dopełniając oczyszczającego aktu.

W Pierścieniu ani władca bogów Wotan, ani Zygfryd nie są postaciami bez skazy. Przy całej ambiwalencji charakterów postaci te cechuje jednak heroiczna wielkość. Natomiast Alberich i jego brat Mime (który również pragnie zdobyć pierścień i próbuje wykorzystać Zygfryda jako swoje narzędzie) są wcieleniem zła wzbudzającym tylko pogardę i odrazę. Oprócz ujawniających się w przebiegu akcji negatywnych cech psychicznych, takich jak odrzucenie miłości, chęć zysku, żądza władzy, zakłamanie i egoizm, karły naznaczone są też pod względem fizycznym. Alberich jest wstrętny i niezgrabny, wzbudza odrazę córek Renu. Mime jest tak brzydki, że Zygfryd domyśla się, że nie może być jego synem, intuicyjnie wyczuwa swoją przynależność do innej, wyższej rasy. Przeglądając się w potoku, Zygfryd odkrywa: „Tam ujrzałem też/ mój własny obraz;/ całkiem inny niż ty/ wydałem się sobie wtedy:/ takie podobieństwo zachodzi między ropuchą/ a błyszczącą rybą;/ ale nigdy jeszcze ryba nie wypełzła z ropuchy" ${ }^{39}$.

W Pierścieniu Nibelunga zaznaczony zostaje również aspekt kreatywności, podzielony zgodnie z dychotomicznym myśleniem Wagnera między postaci Mimego i Zygfryda. Mime jest kowalem, który mimo wielu lat praktyki nie potrafi ukuć miecza z zachowanych szczątków. Jego wysiłki są żałosne. Natomiast jasnowłosy Zygfryd ma wrodzone zdolności, niezależne od wykształcenia. To, co nie udaje się karłowi Mime, Zygfrydowi nie sprawia trudności, odzyskanie miecza jest dziełem chwili.

Parsifal był dla Wagnera dziełem szczególnym, dlatego kompozytor zastrzegł sobie, że może ono być wykonywane jedynie w teatrze w Bayreuth. W liście do króla Ludwiga II Wagner objaśniał, że pragnie w ten sposób ustrzec „to najbardziej chrześcijańskie ze wszystkich dzieł sztuki [...] przed światem, który rozpływa się w tchórzliwym strachu przed Żydami”»0. Określając Parsifala jako dzieło chrześcijańskie, Wagner miał na myśli ideę aryjskiego chrześcijaństwa ${ }^{41}$.

\footnotetext{
38 Por. R. Wagner, Siegfried, Stuttgart 2007, s. 62.

39 Fizyczne cechy postaci z oper Wagnera i ich związek z XIX-wiecznym stereotypowym wyobrażeniem Żyda omawia Marc A. Weiner we wspomnianej już wcześniej książce Antisemitische Phantasien, wykazując, że antysemickie wyrażenia obecne są u Wagnera nie tylko w warstwie słownej, ale również w muzycznej.

40 Richard Wagner, list do króla Ludwiga II z dnia 25 VIII 1879, [cyt. za:] P. L. Rose, op. cit., s. 244: „dies christlichste aller Kunstwerke [...] vor einer Welt, welche in Feigheit vor den Juden vergeht".

41 Szczegółowe uzasadnienie tego twierdzenia przedstawiają Paul Rose (op. cit., s. 244-258) i Hartmut Zelinsky (Richard Wagners „Kunstwerk der Zukunft” und seine Idee der Vernichtung, [w:] Von kommenden Zeiten. Geschichtsprophetien im 19. und 20. Jahrhundert, red. J. H. Knoll, J. H. Schoeps, Stuttgart-Bonn 1984, s. 84-106).
} 
Titurel otrzymał zadanie strzeżenia Świętego Graala, naczynia, z którego Zbawiciel pił w czasie ostatniej wieczerzy, do którego spływała krew z jego zranionego boku, a także włóczni, która przebiła jego bok. W zadaniu tym wspierają go rycerze, tworzący społeczność Graala. Należeć do niej może jedynie ten, kto zachowa czystość. Klingsor pragnie przyjęcia do szlachetnej wspólnoty, nie radzi sobie jednak z własną słabością. Aby dorównać rycerzom Graala, Klingsor sam się kastruje. Mimo to zostaje przez Titurela wykluczony z zakonu Graala, ponieważ czynem tym udowadnia jedynie własną słabość, a jego wstrzemięźliwość seksualna jest sztuczna. Odrzucony Klingsor przebywa w swoim zamku pełnym przepychu i bogactwa oraz pięknych dziewcząt, zmysłowych pokus wabiących rycerzy Graala. Jego najdoskonalszym narzędziem jest czarodziejka Kundry. Ona to oczarowuje swoim urokiem Amfortasa, któremu wiekowy Titurel powierzył swój urząd. Wykorzystując słabość Amfortasa, Klingsor kradnie świętą włócznię i zadaje mu nią cios w bok. Amfortas jest śmiertelnie ranny, wybawić go może jedynie „czysty prostaczek/ wiedziony przez współczucie” Parsifal.

Żadna z postaci Parsifala nie przypomina żałosnych karykatur, jakimi byli Beckmesser ze Śpiewaków norymberskich oraz Alberich i Mime z Pierścienia Nibelunga. A jednak i tutaj występują postaci naznaczone negatywnie, które można uznać za obrazy Żydów. W pamiętniku Cosimy znajduje się zapis o tym, że Wagner uważał Klingsora i Albericha za postaci podobne ${ }^{43}$. Klingsor jest w Parsifalu wcieleniem zła, wyrzeka się miłości, sam się kastrując, i dąży do władzy, pożądając Graala; kradnie też świętą włócznię, jego zachowanie przypomina czyny Albericha z Pierścienia. Jego przeciwnikiem jest Parsifal, Zbawiciel, którego cechuje „współczucie”. „Współczucie” jest według Wagnera cechą wyłącznie aryjską, nieznaną Żydom ${ }^{44}$. Postacią żydowską jest oprócz Klingsora także Kundry, o czym świadczy jedno z jej wielu imion, Herodias (Herodiada) ${ }^{45}$. Klingsor nazywa ją „pradiablicą" ${ }^{6} \mathrm{i}$ „piekielną różą". Jak pisze Wagner w szkicu prozą z 1865 roku, jest ona kobiecym wariantem „Żyda Wiecznego Tułacza”, Ahaswera ${ }^{47}$. Klingsor powierza Kundry zadanie uwiedzenia Parsifala, który jednak opiera się jej urokowi. Parsifal odzyskuje włócznię zrabowaną przez Klingsora i czyniąc nią znak krzyża, powoduje zniknięcie czarodziejskiego ogrodu i zamku, przełamuje zatem krąg zła. Odtrącenie przez Parsifala oznacza dla Kundry nawrócenie, od tego momentu służy ona Parsifalowi, ubrana w pokutne szaty obmywa mu nogi jak Maria Magdalena Jezusowi. Wreszcie Parsifal dotyka włócznią rany Amfortasa i ją ulecza, odsłania również Graala, który w czasie choroby Amfortasa pozostawał zamknięty. Światło Graala ma zbawczą moc, udzieloną także Kundry, która nareszcie znajduje wybawienie od wiecznej wędrówki i umiera. Jednym z pierwszych komentujących fakt zbawienia Kundry był Theodor Adorno: „Głoszona tam [w Parsifalu] religia miłości i współczucia jest warta nie więcej niż deklaracje Hermanna Göringa na temat ochrony zwierząt. U Wagnera 'zbawienie' jest równoznaczne ze zniszczeniem: jeżeli Kundry zostaje wybawiona, równie

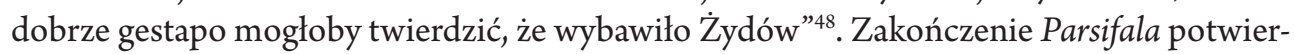

${ }^{42}$ R. Wagner, Parsifal, Leipzig o. J., s. 32: „durch Mitleid wissend/ der reine Tor”.

${ }^{43}$ C. Wagner, op. cit., s. 52.

44 P. L. Rose, op. cit., s. 252.

${ }^{45}$ Por. Nowy Testament, Mk 6: 14-29, Mt 14: 1-12, Łk 9: 7-9.

${ }^{46}$ R. Wagner, Parsifal, s. 43: „Urteufelin! Höllenrose!”. Por. uwagi Marca Weinera na temat podobieństwa obrazów diabła i Żyda w kulturze zachodniej, M. Weiner, op. cit., s. 309-310.

${ }^{47}$ D. Borchmeyer, Das Theater Richard Wagners. Idee, Dichtung, Wirkung, Stuttgart 1982, s. 293.

${ }^{48}$ T. W. Adorno, Wagner, Nietzsche, und Hitler, [w:] idem, Gesammelte Schriften, red. R. Tiedemann, t. 19, Frankfurt a. M. 1971, s. 411. 
dza, że wspólnota Graala reprezentuje aryjskie chrześcijaństwo, a Parsifal Zbawiciela oczyszczonego z żydowskiego pochodzenia. Giermkowie i rycerze, przyjmując błogosławieństwo Graala, wołają: „Zbawienie dla Zbawiciela!”49.

Ideologia zawarta w operach Wagnera stała się „narkotykiem dla marzeń [Hitlera] o władzy" 50 . Ogniwami łączącym Wagnera z Hitlerem były także powstające od 1870 roku tzw. Związki Wagnerowskie oraz Houston Stewart Chamberlain, przywódca ruchu z Bayreuth, przyjaciel Cosimy i mąż Ewy Wagner (córki Cosimy i Ryszarda). Swoją ideologię rasistowską, stanowiącą podsumowanie i kontynuację linii obranej przez Ryszarda Wagnera, Chamberlain przedstawił w Grundlagen des 19. Jahrhunderts, publikacji, pod której wpływem pozostawały szczególnie kręgi intelektualne i arystokracja ${ }^{51}$. Hitler wydał się choremu Chamberlainowi oczekiwanym zbawcą i następcą - Hitler-Parsifal przyjął z rąk Chamberlaina-Amfortasa posłannictwo, a namaszczenie to uwierzytelniło najbardziej uwodzicielski aspekt narodowego socjalizmu: „wiarę w zbawcę i narodową regenerację" ${ }^{\text {"2 }}$. Kiedy Hitler po nieudanym puczu przebywał $\mathrm{w}$ areszcie $\mathrm{w}$ Landsbergu, Chamberlain $\mathrm{i}$ cała rodzina Wagnera wyrażali publicznie swoje poparcie dla niego. Winifred Wagner założyła w Wahnfried „punkt zbiorczy dla paczek miłości do Landsbergu” ${ }^{33}$. W paczkach tych znalazły się oprócz rzeczy praktycznych, takich jak koce, również książki oraz papier, na którym Hitler napisał Mein Kampf $f^{54}$.

Odtąd para Winifred Wagner i Adolf Hitler ucieleśnia na długie lata związek polityki i kultury pod narodowosocjalistycznym sztandarem. Bayreuth staje się „nadwornym teatrem Hitlera" ${ }^{55}$, a Bayreuther Blätter i Festspielführer instrumentami nazistowskiej propagandy. W liście do Siegfrieda Wagnera z 5 V 1924 roku Hitler pisze znamienne słowa: w Bayreuth „najpierw przez mistrza, a potem przez Chamberlaina wykuty został duchowy miecz, którym my dzisiaj walczymy" ${ }^{56}$. To wyznanie stanowi najbardziej bezpośrednie wskazanie Hitlera na ideologię Wagnera jako filar jego szatańskiej misji. Inne dowody są bardziej zaszyfrowane ${ }^{57}$.

Hitler dokładnie znał dzieła Wagnera. Pierwszą operą Wagnera, jaką obejrzał, był Lohengrin w Linzu, o czym wspomina w Mein Kampf: „W jednej chwili byłem oczarowany. Młodzieńczy zachwyt dla mistrza z Bayreuth nie znał granic. Jego dzieła przyciągały mnie ciągle

49 R. Wagner, Parsifal, s. 70: „Erlösung dem Erlöser!”.

${ }^{50}$ E. Hanisch, Ein Wagnerianer namens Hitler, [w:] Richard Wagner 1883-1983. Die Rezeption im 19. und 20. Jahrhundert. Gesammelte Beiträge des Salzburger Symposiums, red. U. Müller, Stuttgart 1984, s. 71. Por. również opinię Joachima Festa, który uważa, że pisma i opery Wagnera stworzyły „ideologiczne środowisko, które najbardziej odpowiadało obawom i potrzebom triumfu, odczuwanym przez Hitlera" (J. Fest, Hitler. Eine Biographie, Berlin 1998, s. 100

51 J. Köhler, Wagners Hitler. Der Prophet und sein Vollstrecker, München 1997, s. 18.

52 H. R. Vaget, Wieviel "Hitler" ist in Wagner? Anmerkungen zu Hitler, Wagner und Thomas Mann, [w:] Richard Wagner und die Juden, s. 201.

53 B. Hamann, Winifred Wagner oder Hitlers Bayreuth, München 2003, s. 99.

54 Por. ibidem, s. 99.

55 Ibidem, s. 260.

${ }^{56}$ List Adolfa Hitlera do Siegfrieda Wagnera z 5 V 1924, [cyt. za:] H. R. Vaget, op. cit., s. 181: „erst durch den Meister und dann durch Chamberlain, das geistige Schwert geschmiedet wurde, mit dem wir heute fechten”.

57 Saul Friedländer uważa, że w mowach Hitlera i w Mein Kampf nie ma ani jednej wzmianki o antysemickich pismach Wagnera. (Por. S. Friedländer, Bayreuth und der Erlösungsantisemitismus, [w:] Richard Wagner und die Juden, s. 17). Twierdzenie to jest słuszne, jeżeli wziąć pod uwagę bezpośrednie odwołania. Z mojej analizy wynika jednak, że Hitler posługuje się obrazami, postaciami, a nawet cytatami o antysemickiej wymowie, zaczerpniętymi z oper Wagnera. 
na nowo" ${ }^{8}$. O tym, że liczył się dla niego każdy szczegół, świadczyły jego własne pomysły dotyczące inscenizacji. Benno von Arent uwzględnił wskazówki Hitlera, realizując przedstawienie Śpiewaków norymberskich, które w 1935 roku w Operze Norymberskiej zainaugurowało zjazd NSDAP. Hitler przedłożył Arentowi ponadto szkice do Tristana i Izoldy oraz całego Pierścienia Nibelunga ${ }^{59}$. Interesował się również pismami Wagnera. W 1935 roku Winifred Wagner przygotowywała wydanie korespondencji Wagnera z królem Ludwikiem II. Hitler kazał sobie przesłać do Monachium cały zbiór odpisów i studiował je. To właśnie w tym zbiorze znajduje się cytat, który mógł mu dostarczyć uzasadnienia dla jego celów politycznych. W jednym z listów Wagner pisze do króla Ludwika, że uważa „rasę żydowską za urodzonego wroga ludzkości i wszystkiego, co w niej szlachetne: pewne jest mianowicie, że my, Niemcy, przez nich upadniemy, i może jestem ostatnim Niemcem, który jako człowiek sztuki zdołał wytrwać przeciwko judaizmowi, który już wszystko opanował"60.

O tym, że Hitler wykorzystywał dzieła teoretyczne i operowe Wagnera jako źródła inspiracji, świadczą sformułowania w jego mowach, które można podzielić na trzy grupy pod względem sposobu ich powiązań z twórczością mistrza z Bayreuth: 1) pokrewieństwo ideologiczne między mowami Hitlera a pismami Wagnera, 2) wykorzystywanie w mowach Hitlera zwrotów zaczerpniętych z utworów Wagnera oraz 3) posługiwanie się obrazami czy postaciami pochodzącymi z tych dzieł.

Pokrewieństwo ideologiczne widoczne jest np. w Mein Kampf. Hitler, podobnie jak Wagner, stwierdza, że Żydzi nie są zdolni do kreatywnej działalności i nie posiadają tradycji kulturowych, na których mógłby się opierać ich dalszy rozwój. Osiągnięcia duchowe Żydów polegają na pasożytowaniu na kulturze obcej. Do cech, które Hitler wymienia u Żydów, należy „najskrajniejszy egoizm” ${ }^{1}$, co Wagner w pamflecie Żydostwo w muzyce kilkakrotnie akcentowal, a na scenie operowej przedstawił w takich postaciach, jak Beckmesser, Mime, Alberich. Pamflet ten zdaje się przebijać też przez cały ustęp z Mein Kampf dotyczący umiejętności językowych Żydów. Żydzi, przebywając w Niemczech, dopuszczają się oszustwa podawania się za Niemców. Oczywiście mogą oni przyswoić sobie język niemiecki, ale zawsze można ich poznać po tym, że ten język kaleczą ${ }^{62}$. Czystość rasy nie leży jednak w języku, ale we krwi. Wyrażając się w obcym języku, Żydzi i tak wyrażają stare, właściwe im treści: „To pokazuje najlepiej Żyd, który może mówić tysiącem języków i mimo to pozostanie czystym Żydem" ${ }^{\prime 3}$.

Przykładem wykorzystywania przez Hitlera dosłownych sformułowań z oper Wagnera jest słynne hasło: „Zaczynajcie!”, z III aktu Śpiewaków norymberskich ${ }^{64}$, którego w marcu 1934 roku Hitler użył w Unterhaching, w przemowie z okazji rozpoczęcia budowy autostrady München-Salzburg. W ten sposób „der Merker” daje hasło do rozpoczęcia konkur-

${ }^{58}$ A. Hitler, Mein Kampf, München 1943, s. 49: „Mit einem Schlage war ich gefesselt. Die jugendliche Begeisterung für den Bayreuther Meister kannte keine Grenzen. Immer wieder zog es mich zu seinen Werken [...]".

59 Por. B. Hamann, op. cit., s. 305.

60 Ibidem, s. 360: „die jüdische Race für den geborenen Feind der Menschheit und alles Edlen in ihr: daß namentlich wir Deutschen an ihnen zugrunde gehen werden, ist gewiß, und vielleicht bin ich der letzte Deutsche, der sich gegen den bereits alles beherrschenden Judaismus als künstlerischer Mensch aufrechtzuerhalten wußte".

61 Por. A. Hitler, op. cit., s. 331

62 Por. ibidem, s. 342.

${ }^{63}$ Ibidem: „Dies zeigt am allerbesten der Jude, der in tausend Sprachen reden kann und dennoch immer der reine Jude bleibt".

${ }^{64}$ Por. J. Köhler, op. cit., s. 358. 


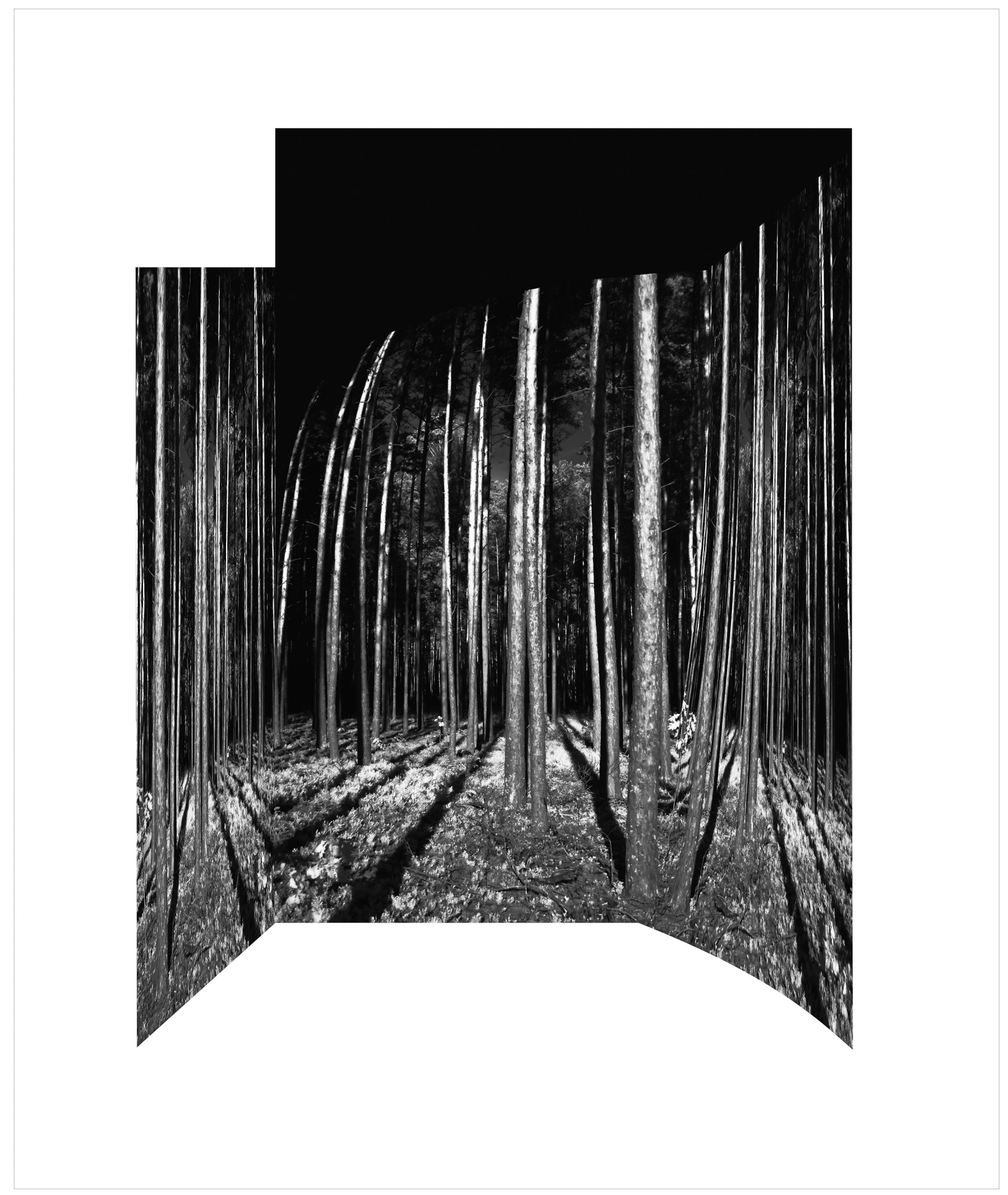

Przestrzeń - 004 
su śpiewaków. Tymi też słowami Walther von Stolzing rozpoczyna swoją pieśń o wiośnie i miłości, która co prawda nie spotyka się z uznaniem sędziów-rzemieślników, ale dla Hansa Sachsa, jedynego, który jest w stanie ją docenić, jest świadectwem geniuszu, dziełem twórcy nietrzymającego się ściśle dawnych reguł, ponieważ swym dziełem ustanawia nowe prawa. Charakterystyczny jest fragment pieśni Walthera mówiący o wywołanej przez wiosnę fali, która narasta, ogarniając cały las. Fragment ten z perspektywy Hitlera na pewno mógł być odczytany jako metafora przybierającego na sile ruchu narodowosocjalistycznego.

Słynny cytat ze Śpiewaków norymberskich pojawia się zresztą nie tylko w przemowie Hitlera, posługuje się nim również Julius Streicher w bardziej drastycznym kontekście. W jego przemowie z 10 VIII 1938 roku, poprzedzającej akt zburzenia synagogi w Norymberdze, znowu rozbrzmiewa zawołanie operowego Hansa Sachsa: „Robotnicy norymberscy, którzy niegdyś byliście niewolnikami Żydów i którzy teraz radośnie pomagacie budować nową Rzeszę Adolfa Hitlera, niniejszym daję Wam historyczny rozkaz - Zaczynajcie!"”5 . Destrukcyjna akcja nazistów mogła być w ich wyobrażeniu wypełnieniem woli Wagnera, który w swoim eseju Wollen wir hoffen? z 1879 roku zaznacza, że opera Śpiewacy norymberscy została przyjęta przez Żydów bardzo nieprzychylnie, i oburza się z powodu zbudowania w Norymberdze naprzeciwko pomnika Hansa Sachsa „imponującej synagogi czystego orientalnego stylu" 66 .

Wyróżniony przeze mnie trzeci obszar zapożyczeń, postaci i obrazy, reprezentuje np. postać karła. Hitler stosuje ją z upodobaniem, określając w ten sposób swoich wrogów, którym przypisuje cechy rzekomo semickie. Zapożyczenie tej postaci z Pierścienia Nibelunga wydaje się wielce prawdopodobne, zwłaszcza że kilka razy w tym kontekście pada również imię Alberich ${ }^{67}$. W Mein Kampf Hitler wyraża pogląd, że cała gospodarka została opanowana przez Żydów, którzy w swoim nienasyceniu dążą do powiększenia swych wpływów. $\mathrm{Z}$ tego dążenia wynika chęć emancypacji i starania o przyznanie Żydom praw obywatelskich państwa, w którym się osiedlili. Obraz, którym posługuje się Hitler, aby zilustrować swoją wypowiedź, przywodzi na myśl sceny ze Złota Renu, opery rozpoczynającej cykl Pierścień Nibelunga. Hitler stwierdza, mając na myśli Żydów: „im wyżej się wspina, tym bardziej swobodnie wznosi się spoza zasłony przeszłości jego dawny, niegdyś mu obiecany cel, i z gorączkową żądzą jego najjaśniejsze głowy widzą, jak sen panowania nad światem

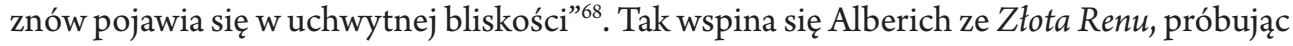
schwytać córki Renu ${ }^{69}$. Córki Renu, zwiewne i powabne, igrają z brzydkim, niezdarnym

65 Fränkische Tageszeitung z 11 VIII 1938: „Ihr Nürnberger Arbeiter, die ihr einst Sklaven der Juden gewesen seid und die ihr jetzt freudig mithelft, das neue Reich Adolf Hitlers zu bauen, nun gebe ich euch den geschichtlichen Auftrag: Fanget a n!", podkreślenie K. Sz.-P.

${ }^{66}$ R. Wagner, Wollen wir hoffen?, [w:] idem, Sämtliche Schriften und Dichtungen, t. 10, s. 120: „eine imponierende Synagoge reinsten orientalischen Stiles".

67 Imię Alberich pada np. w artykule z 30 III 1929, opublikowanym w Illustierter Beobachter. Hitler podejmuje w nim temat szerzącego się w Rosji „żydowskiego” bolszewizmu, stwierdzając, że „panowanie Albericha [...] dziś [...] w Rosji spełniło się bez reszty". (K. Lankheit, Hitler. Reden, Schriften, Anordnungen, t. 3, Cz. 2, München 1994, s. 124).

${ }^{68}$ A. Hitler, op. cit., s. 343: „denn je höher er klimmt, um so lockerer steigt aus dem Schleier der Vergangenheit sein altes, ihm einst verheißenes Ziel heraus, und mit fiebernder Gier sehen seine hellsten Köpfe den Traum der Weltherrschaft schon wieder in faßbare Nähe rücken".

69 Por. R. Wagner, Das Rheingold, Stuttgart 2007, s. 8: „Aus einer finstern Schlufft ist während dem Alberich, an einem Riffe klimmend, dem Abgrunde entstiegen“. Por. też ibidem, s. 19: „Er macht sich mit verzweifelter Anstrengung zur Jagd auf; mit grauenhafter Behendigkeit erklimmt er Riff für Riff [...], er strauchelt, stürzt in den Abgrund hinab, klettert dann hastig wieder zur Höhe [...]". 
karłem, pojawiając się „w uchwytnej bliskości”, by w momencie, gdy karłowi wydaje się, że je schwyci, umknąć z perlistym śmiechem. Alberich nie daje za wygraną, „z gorączkową żądzą", żałosny w swych wysiłkach, próbuje się zbliżyć do nimf, uważając, że to mu się należy: „Jakiż w członkach/ żarliwy żar/pali mnie i pali! [...] Jakżesz się śmiejecie i kłamiecie,/ pożądliwie was łaknę,/ jedna z was musi mi ulec!”70 „Zasłona”, wspomniana przez Hitlera, także wpisana jest w scenę ze Złota Renu. Zgodnie z wskazówkami scenicznymi w podwodnym świecie panuje zielonkawy zmierzch. Im głębiej, tym bardziej wodna toń przypomina coraz delikatniejszą, wilgotną mgłę ${ }^{71}$ W tej mgle odbywają się igraszki nimf i Albericha. Nagle wodna toń rozświetla się, wyłania się z niej złoto Renu. Alberich, który przed chwilą gorączkowo pożądał nimf, wyrzeka się miłości i kradnie skarb, uruchamiając krąg zła, prowadzący do końcowej katastrofy: zmierzchu bogów. Kradnie złoto Renu, które daje mu władzę nad światem: „Świata dziedzictwo/ zdobyłby na własność ten,/ kto ze złota Renu/ stworzyłby pierścień,/ który dałby mu bezgraniczną władzę"72.

Hitler w Mein Kampf stwierdza ponadto, że Żydzi wykorzystują i plądrują inne narody, ale starają się to ukryć, przybierając postawę męczenników. Wiele wysiłku wkładają w to, aby wmówić swoim ofiarom, że są „przyjaciółmi ludzkości”73. Żyd skrzętnie ukrywa swoje niecne czyny i głośno podkreśla, jak bardzo cierpi z powodu cierpienia innych i jakie to ofiary musiał ponieść, aby przyjść innym z pomocą ${ }^{74}$. Rozgłasza swoje zasługi wszem i wobec, kto w nie nie wierzy, jest wobec niego niesprawiedliwy. W krótkim czasie udaje mu się sprawy tak poprzekręcać, że wygląda, jakby to on był ofiarą, a nie oprawcą. Opis ten kojarzy się ze scenami, które rozgrywają się w trzeciej części Pierścienia Nibelunga, operze Zygfryd, między Zygfrydem a karłem Mime. Mime jest bratem Albericha; jego celem jest zdobycie pierścienia ${ }^{75}$ i objęcie panowania nad światem. Do tego celu potrzebny mu jest Zygfryd, który jest w stanie pokonać smoka, aktualnego posiadacza pierścienia. Zygfryd nienawidzi Mimego, który go wychowuje po tragicznej śmierci rodziców. Mime stara się uczynić z Zygfryda posłuszne narzędzie i przekonać go o tym, że jest przezeń niesprawiedliwie osądzany. Żałosne skargi Mimego wykazują nieskrywane podobieństwo do cytowanych słów Hitlera. Kojarzą się z nimi też zabiegi karła, mające na celu przekonanie Zygfryda, że kieruje się on wylącznie dobrem swojego wychowanka: „O niewdzięczne,/ złe dziecko!/ Teraz posłuchaj, za co ty mnie nienawidzisz!/ Nie jestem ci ojcem/ ni krewnym, - / a mimo to zawdzięczasz mi siebie!/ Całkiem obcy mi jesteś,/ swemu jedynemu przyjacielowi/ wyłącznie z litości/ cię tutaj schowałem:/ i mam teraz miłą nagrodę!/ A cóż ja też głupi miałem nadzieję na wdzięczność?”76.

70 Ibidem, s. 18: „Wie in den Gliedern/ brünstige Glut/ mir brennt und glüht! [...] Wie ihr lacht und lügt, / lüstern lechz' ich nach euch, und eine muss mir erliegen!"

71 Ibidem, s. 7.

72 Ibidem, s. 22: „Der Welt Erbe/ gewänne zu eigen,/ wer aus dem Rheingold/ schüfe den Ring,/ der maßlose Macht inm verlieh".

${ }^{73}$ A. Hitler, op. cit., s. 343: „Ja, es ist eine mühsame Arbeit sich den abgehäuteten Opfern auf einmal als 'Freund der Menschen' vorzustellen".

74 Por. ibidem, s. 343-344.

75 Pierścień został przez Albericha odlany ze skradzionego złota Renu. W międzyczasie przeszedł przez ręce Wotana, który odebrał go Alberichowi, ale spętany umową, musiał oddać go olbrzymom. Pierścień niszczy każdego, kto ma go w posiadaniu. Między olbrzymami (braćmi) dochodzi do walki, Fafner zabija Fasolta, przemienia się w smoka i zapada w leśnej pieczarze w burżuazyjny sen, strzegąc dostępu do pierścienia: „Leżę i posiadam" („Ich lieg' und besitze", R. Wagner, Siegfried, s. 62.

${ }^{76}$ Ibidem, s. 19-20: „O undankbares,/ arges Kind!/ Jetzt hör, wofür du mich hassest!/ Nicht bin ich Vater/ noch Vetter dir,-/ und dennoch verdankst du mir dich!/ Ganz fremd bist du mir,/ deinem einz'gen Freund;/ aus Erbarmen allein/ barg ich dich hier:/ nun hab' ich lieblichen Lohn!/ Was verhofft' ich Tor mir auch Dank?" 
Elementy zaczerpnięte z dzieł Wagnera pełniły w mowach Hitlera funkcję środków retorycznych. Do estetyzacji polityki nazistowskiej wykorzystywana była natomiast muzyka Wagnera i całe opery. Muzyka Wagnera uświetniała uroczystości odbywające się w III Rzeszy. Kiedy 13 V 1934 roku odbyło się w Bayreuth spotkanie Ernsta Röhma z oddziałami SA, w którym wzięło udział 25000 żołnierzy, podczas parady na Marktplatz rozbrzmiewały dźwięki Pochodu bogów ze Złota Renu ${ }^{77}$. W chwilach opłakiwania odejścia kogoś sięgano po marsza żałobnego ze Zmierzchu bogów. Odegrano go np. 8 III 1935 roku na pogrzebie Gauleitera Schemma ${ }^{78}$, w lutym 1943 marsz żałobny posłużył jako apoteoza klęski 6. Armii pod Stalingradem ${ }^{79}, 30$ IV 1945 roku nadały go stacje radiowe jako muzyczne tho sprawozdania informującego o śmierci Hitlera i Ewy Braun ${ }^{80}$. Stałym przebojem w NS-Wochenschauen było Cwałowanie Walkirii, ilustrujące muzycznie reportaże o zwycięskich atakach powietrznych wojsk niemieckich ${ }^{81}$.

Opery Wagnera wykorzystywane byly jako oprawa muzyczna oraz ideologiczna podbudowa zjazdów NSDAP. Tak było np. w czasie „Zjazdu wolności” w 1935 roku (Reichsparteitag der Freiheit), na którym uchwalono „prawa norymberskie”, zakazujące zawierania małżeństw i pozamałżeńskich stosunków między Żydami i Aryjczykami. Kiedy Führer przybył do ratusza, aby przyjąć replikę starego „miecza Rzeszy”, rozbrzmiewał chór Wacht auf ze Śpiewaków norymberskich. Wieczorem uczestnicy zjazdu mogli obejrzeć tę operę w całości pod dyrekcją Wilhelma Furtwänglera i z gwiazdami teatru w Bayreuth w obsa$\mathrm{dzie}^{82}$. Dziękując Furtwänglerowi za jej wykonanie, Hitler określił Śpiewaków norymberskich jako „naszą prawdziwą niemiecką operę ludową"83. Zjazd, którego motywem przewodnim była czystość rasy i nienawiść do Żydów, zakończył się odegraniem marsza Nibelungów z Pierścienia oraz uwerturą do opery Rienzi ${ }^{84}$.

Wagner i jego opery dostarczyły Hitlerowi wskazówek do inscenizacji własnego życia i śmierci. Jako następca mistrza z Bayreuth, Hitler wykonywal jego wolę, organizując festiwale wojenne. Festiwal w Bayreuth już w roku 1933, kiedy to Hitler przejął władzę, miał kłopoty z publicznością, zabrakło na nim przecież cudzoziemców, „Żydów, demokratów, liberałów, komunistów, socjaldemokratów, wolnomularzy, homoseksualistów" ${ }^{85}$. Aby zapełnić amfiteatr, Hitler rozdał nieodpłatnie 10000 biletów dla tych, „którzy zasłużyli, aby się tu podbudować niemiecką sztuką" ${ }^{86}$. Byli to funkcjonariusze partyjni, którym rozkazano pojechać na festiwal ${ }^{87}$. Od roku 1940 roku publiczność w Bayreuth tworzyli na polecenie Hitlera ranni żołnierze z personelem pielęgniarskim oraz pracownicy przemysłu zbrojenio-

77 Por. B. Hamann, op. cit., 278.

78 Por. ibidem, s. 300.

79 Por. S. Friedländer, op. cit., s. 16.

80 Por. B. Hamann, op. cit., s. 506.

81 J. M. Fischer, Wagner-Interpretation im Dritten Reich. Musik und Szene zwischen Politisierung und Kunstanspruch, [w:] Richard Wagner im Dritten Reich. Ein Schloss Elmau-Symposion, red. S. Friedländer, J. Rüsen, München 2000, s. 145. Takie zastosowanie muzyki Wagnera zostało sparodiowane w filmie Apokalypse Now Francisa Forda Coppoli.

82 Por. J. Köhler, op. cit., s. 354.

${ }^{83}$ B. W. Wessling, Furtwängler. Eine kritische Biographie, Stuttgart 1985, s. 23: „unsere [...] eigentliche [...] Volksoper".

${ }^{84}$ Por. J. Köhler, op. cit., 355.

85 B. Hamann, op. cit., s. 259.

${ }^{86}$ Richard-Wagner-Festspiele Bayreuth 1941, Berlin 1941, s. 13, [cyt. za:] J. Köhler, op. cit., s. 380: „an solche, die es wert waren, sich hier an deutscher Kunst und Art zu erbauen“.

87 Por. B. Hamann, op. cit., s. 260. 
wego. Hitler za pośrednictwem organizacji Kraft durch Freude płacił za podróż, pobyt i bilety wstępu. To „uniesienie duchowe [...], jakie może dać jedynie czysta sztuka”"88, miało być podziękowaniem Führera za ich trud. W przeddzień każdego przedstawienia „goście Führera” brali udział w wykładach wyjaśniających dany utwór, tłumaczono im też, gdzie mają klaskać. Szczególnie postać Zygfryda nadawała się do celów propagandowych: „Ze szczątków złamanej broni naszych ojców miecz wytopił człowiek, który 'nie zaznał strachu'. W jasnej zbroi, ufając jedynie własnej sile, stoją oto Zygfrydowskie Niemcy"89.

Hitler był w swoim przekonaniu nie tylko następcą Wagnera, ale też inkarnacją różnych postaci z jego oper. Jako przykład identyfikacji Hitlera wymienić można Wotana, władcę bogów z Pierścienia Nibelunga. Hitler, podróżując incognito, posługiwał się przydomkiem Wolf, który w operze Wagnera jest jednym z imion Wotana ${ }^{90}$, Wolf pojawia się też jako człon w innych stworzonych w okresie III Rzeszy nazwach (Wolfsburg, Wolfsschanze). Innym wzorem dla Hitlera był Rienzi, ostatni trybun. Alfred Kubizek, przyjaciel Hitlera z lat młodości, nazywany przez niego Gustl, opisuje jego ekstatyczne przeżycia związane z operą Rienzi, której główny bohater był przywódcą ruchu przeciw skorumpowanym rządom Rzymian i ściągnął na siebie gniew Kościoła katolickiego. Obydwa aspekty odpowiadały stanowisku Hitlera, który występował zarówno przeciw rządowi austriackiemu, jak i Kościołowi katolickiemu. Już jako kanclerz III Rzeszy miał powiedzieć do Kubizka o tym przedstawieniu: „W tej godzinie zaczęło się" ${ }^{\prime \prime 1}$, wskazując na korzenie swojej politycznej misji. O znaczeniu postaci trybuna jako ideologicznego wzoru Hitler mówił do Roberta Leya:

Wie Pan, Panie Ley, nieprzypadkowo każę inaugurować Zjazdy Partii uwerturą do opery ‘Rienzi'. To nie jest tylko kwestia muzyczna. Ten syn małego właściciela gospody w wieku 24 lat przywiódł rzymski lud do tego, by przepędził skorumpowany senat, a osiągnął to, przypominając o wspaniałej przeszłości imperium. Przy tej opatrzonej błogosławieństwem Boga muzyce jako młody człowiek miałem $\mathrm{w}$ teatrze $\mathrm{w}$ Linzu natchnienie, że mnie też musi się udać zjednoczyć niemiecką rzeszę i uczynić ją wielką ${ }^{92}$.

„Heil Hitler”, rozbrzmiewające w czasie dyktatury nazistowskiej w całych Niemczech, przypomina okrzyk ludu rzymskiego, witającego w operze Rienzi nowo wybranego trybu-

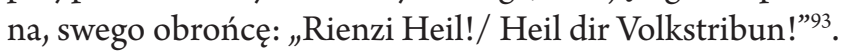

Nawet $\mathrm{w}$ chwili śmierci Hitler utożsamia się z heroicznymi postaciami z oper Wagnera. 22 IV 1945 uznaje wojnę za przegraną i postanawia się zastrzelić. Swoją śmierć traktuje jako konieczną ofiarę, która jest zapowiedzią przyszłego odrodzenia ruchu narodowoso-

${ }^{88}$ B. Hamann, op. cit., s. 408: „eine seelische Erhebung [...] wie sie nur reine Kunst zu spenden imstande ist".

89 Ibidem, s. 413: „Aus den Stücken der zerbrochenen Waffe unserer Väter hat es der Mann geschweißt, der 'das Fürchten nie erfuhr'. In heller Wehr, allein auf die eigene Kraft vertrauend, steht Siegfried-Deutschland nur da".

90 Por. np. R. Wagner, Die Walküre, s. 15, słowa Siegmunda do Hundinga: „Wolfe, der war mein Vater”

91 Por. G. Victor, Hitler: The Pathology of evil, Dulles 2000, s. 36, B. Hamann, op. cit., s. 392.

92 A. Speer, Spandauer Tagebücher, Frankfurt a. M. 1975, s. 136: „Wissen Sie, Ley, ich lasse die Parteitage nicht zufällig mit der Ouvertüre von Rienzi eröffnen. Das ist nicht nur eine musikalische Frage. Dieser Sohn eines kleinen Gastwirts hat mit vierundzwanzig Jahren das römische Volk dazu gebracht, den korrupten Senat zu vertreiben, indem er die großartige Vergangenheit des Imperiums beschwor. Bei dieser gottbegnadeten Musik hatte ich als junger Mensch im Linzer Theater die Eingebung, daß es auch mir gelingen müsse, das deutsche Reich zu einen und groß zu machen".

${ }_{93}$ R. Wagner, Rienzi, [w:] idem, Sämtliche Schriften und Dichtungen, t. 1, Leipzig 1911, s. 48. 
cjalistycznego, zmartwychwstania i realizacji jego ideowego dziedzictwa. Widząc siebie i swoją misję w ten sposób, Hitler nawiązuje do idei zbawienia, która w operach Wagnera łączy się z tragiczną śmiercią bohaterów: śmierć jest dla nich obietnicą przyszłego szczęścia, spełnienia, którego nie dało im życie. Niczym Wagnerowska Brunhilda Hitler umiera zatem „, radosnym sercem”" ${ }^{4}$, wierząc $\mathrm{w}$ „promienne odrodzenie ruchu narodowosocjalistycznego i tym samym urzeczywistnienie prawdziwej wspólnoty ludu"95. W Zmierzchu bogów Brunhilda $\mathrm{w}$ radosnym uniesieniu dobrowolnie ginie w płomieniach, zabierając ze sobą swojego ukochanego rumaka Grane. Hitler kopiuje ten element, zabijając swoje psy oraz psy należące do ludzi z jego najbliższego otoczenia.

W operach Wagnera częstym motywem jest wspólna śmierć kochanków: Izolda umiera, opłakując Tristana, Senta rzuca się w morskie fale, by spędzić wieczność w ramionach Holendra, Brunhilda w płomieniach łączy się z Zygfrydem. O ile Zygfryd i Brunhilda za życia stają się ofiarami intrygi Hagena i Günthera i oddalają się od siebie, śmierć przynosi im obojgu duchowe oczyszczenie, pełne zrozumienie i zjednoczenie w miłości. Prawdopodobne wydaje się, że takie zjednoczenie wyobrażał sobie Hitler, kiedy 29 IV 1945, w przeddzień samobójstwa, zdecydował się poślubić Ewę Braun, swoją kochankę. Również po śmierci Hitlera kierowano się opracowanym przez niego planem: zwłoki obojga zawinięto w wełniane koce, złożono do dołu, polano benzyną i podpalono ${ }^{96}$. Śmierć w płomieniach, jakiej życzył sobie Hitler, jest motywem zaczerpniętym z twórczości Wagnera. Brunhilda dobrowolnie rzuca się w płomienie żałobnego stosu Zygfryda, zdradzony trybun ludowy Rienzi i jego siostra Irena, obejmując się, umierają razem w płomieniach, po czym zasypują ich gruzy walącej się wieży Kapitolu. Zwłoki Hitlera i Ewy Braun ludzie towarzyszący Hitlerowi w bunkrze zakopują po spaleniu pod gruzami w kraterze powstałym po wybuchu granatu.

W świetle przytoczonych wyżej przykładów antysemityzm Wagnera oraz fakt nazistowskiej instrumentalizacji jego dzieł nie podlegają dyskusji. Kontrowersje badaczy budzi natomiast problem rozmiarów Wagnerowskiego antysemityzmu oraz kwestia estetycznej autonomii dzieł Wagnera. Stawia się pytania o to, czy Wagner faktycznie zawarł w swoich pismach ideologię fizycznego zniszczenia rasy semickiej, czy miał na myśli zagładę w sensie przenośnym - likwidację cech, które uważał za semickie; czy antysemityzm został wyrażony jedynie w pismach teoretycznych, czy odbija się też w dziełach operowych, a jeżeli tak, to czy dzieła Wagnera mogą/mają prawo dziś funkcjonować jako dzieła sztuki niezależne od ideologii autora.

Wyjściem z tego dylematu mogą być starania o defunkcjonalizację dzieł Wagnera, o uwolnienie ich od poprzednich zastosowań, przejawiające się $\mathrm{w}$ negacji występowania w nich aspektów antysemickich. Taka postawa właściwa była wielu emigrantom, którzy zmuszeni byli opuścić faszystowskie Niemcy, a mimo to pozostali wielbicielami niemieckiej kultury i miłośnikami Wagnera, tzn. nie dostrzegali lub nie chcieli dostrzegać niebezpiecznej ideologii w jego dziełach. W ten sposób myślała o dziełach swojego dziadka Friedelind Wagner, która w czasie II wojny światowej wyemigrowała do Ameryki i radykalnie odcięła

94 A. Hitler, Testament z dnia 29 IV 1945, [cyt. za:] M. Domarus, Hitler. Reden und Proklamationen 1932-1945, t. 2, cz. 2, Wiesbaden 1973, s. 2237: „Ich sterbe mit freudigem Herzen”.

95 Ibidem: „strahlende[...] Wiedergeburt der nationalsozialistischen Bewegung und damit Verwirklichung einer wahren Volksgemeinschaft".

96 Por. J. Köhler, op. cit., s. 30. 
się od poglądów swojej afirmatywnie nastawionej do działań Hitlera rodziny. W jednym z wywiadów wyraziła ona przekonanie, że Ryszard Wagner nie poparłby Hitlera: „Nie ma wątpliwości. Ryszard Wagner, który wolność i sprawiedliwość kochał nawet bardziej niż muzykę, nie mógłby oddychać w hitlerowskich Niemczech [...]”. Friedelind zarzuciła Hitlerowi użycie dzieł Wagnera do swoich celów wbrew intencjom autora: „Mój dziadek nie żyje i nie może się bronić przed tym nadużyciem. Ale ja, jego wnuczka, przemawiam w jego duchu i intencji, mówiąc Państwu: Senta, Lohengrin i Parsifal pochodzą z krain, do których żaden nazista nie wtargnie ze swymi wojskowymi butami [...]. Hitler, bluźnierca przeciw Bogu, bluźni też przeciw Ryszardowi Wagnerowi, czyniąc z niego swojego ulubieńca. Dlatego wyjechałam z Niemiec" ${ }^{\prime 7}$. Podobny dylemat przeżywał Tomasz Mann, dla którego Wagner był wielką inspiracją. W wykładzie z roku 1937 Richard Wagner und Der Ring des Nibelungen pisarz ubolewa z powodu nadużycia, na jakie wystawione są dzieła Wagnera w III Rzeszy.

We współczesnym dyskursie naukowym, jaki toczy się wokół Wagnera, opcję defunkcjonalizacji reprezentują np. Dieter Borchmeyer i Udo Bermbach ${ }^{98}$. Inni badacze, jak np. Paul Lawrence Rose czy Marc Weiner, wykazują, że nie tylko warstwa tekstowa, ale też muzyka Wagnera nosi akcenty antysemickie. Polemika na ten temat ma nierzadko charakter bardzo emocjonalny. Dieter Borchmeyer mówi np. o „teutomaniackim wyzyskiwaniu”99 dzieł Wagnera, którego punktem kulminacyjnym był kult narodowosocjalistyczny, czemu przeciwstawia „cudowną, mityczno-muzyczną konstrukcję teatru wagnerowskiego" ${ }^{100}$. Badaczy podkreślających antysemickie akcenty w dziełach Wagnera Borchmeyer określa jako antywagnerian, którzy swoją antypatię próbują sprzedać jako działalność oświeceniową ${ }^{101}$. Natomiast Paul Lawrence Rose, który wziął udział w konferencji w Bayreuth na temat Richard Wagner und die Juden, zorganizowanej między innymi z inicjatywy Dietera Borchmeyera, uważa ją za próbę „wybielania powiązań Wagnera i Bayreuth z nazistami”, za przykład „korupcji i manipulacji”" ${ }^{102}$.

Uwolnienie dzieła Wagnera od ideologicznego ładunku, jaki zawarł w nim autor, lub stwierdzenie, że ten ładunek w nim nie istnieje i został mu przypisany przez nazistów, leży $\mathrm{w}$ interesie współczesnego odbiorcy, dałoby mu bowiem prawo do etycznie nienagannego rozkoszowania się operami mistrza z Bayreuth. Negacja antysemickich elementów w operach Wagnera byłaby jednak narzuceniem wariantów interpretacyjnych uznanych za poprawne i wykluczeniem innych, niewygodnych. Wiąże się to z uproszczeniem wymowy dzieł Wagnera i umniejszeniem ich wartości artystycznej, która przejawia się właśnie w wielowarstwowości i „niepokojąc[ej] wieloznacznoś[ci]” ${ }^{103}$. Antysemickie akcenty tych dzieł są jedną z wielu warstw w nich obecnych, występują one obok humanistycznego

\footnotetext{
97 Cyt. za: B. Hamann, op. cit., s. 437: „Kein Zweifel. Richard Wagner, der die Freiheit und Gerechtigkeit mehr geliebt hat als selbst die Musik, hätte in Hitlers Deutschland nicht atmen können [...]. Mein Großvater ist tot und kann den Missbrauch nicht wehren. Aber ich, seine Enkelin, spreche in seinem Geist und Sinn, wenn ich Ihnen sage: [Senta, Lohengrin und Parsifal] stammen aus Landschaften, in die kein Nazi seine Militärstiefel setzt [...]. Hitler der Gotteslästerer lästert Richard Wagner, indem er ihn zu seinem Liebling macht. Deshalb bin ich aus Deutschland weggegangen".

98 Por. U. Bermbach, Das ästhetische Motiv in Wagners Antisemitismus, [w:] Richard Wagner und die Juden, S. 59 .

99 D. Borchmeyer, op. cit., s. 303: „teutomanische Ausbeutung”.

100 Ibidem, s. 303: „dem mythisch-musikalischen Wunderbau des Wagnerschen Theaters”.

101 Por. ibidem, s. 303.

102 P. L. Rose, Wagner and the Jews; In his own Words, „The New York Times”, 6 XII 1998.

103 M. Weiner, op. cit., s. 18.
} 
przesłania o zwycięstwie miłości nad żądzą posiadania i władzy, obok refleksji nad niszczeniem natury przez cywilizację i przemysł, obok niezaprzeczalnej prawdy o tym, że kreatywność jest większą wartością niż mozolne konstruowanie czegoś według wyuczonych reguł.

W Izraelu, po zakończeniu II wojny światowej, proces defunkcjonalizacji dzieł Wagnera był dla wielu nie do pomyślenia, nazizm i twórczość Wagnera w świadomości ofiar Holokaustu często łączyły się w jedno. Jedynie właściwym stosunkiem do kompozytora czczonego przez nazistów wydawało się całkowite odrzucenie, czego wynikiem był zakaz wykonywania jego utworów. Zakaz ten okazał się kolejnym, szczególnym rodzajem zastosowania dzieł Wagnera. Zapoczątkowany został 12 XI 1938 roku. Wtedy to Orkiestra Symfoniczna Palestyny, późniejsza Israel Philharmonic Orchestra, odwołała planowane na ten dzień wykonanie uwertury do Śpiewaków norymberskich. Decyzja ta była reakcją na pogrom „nocy kryształowej”104. W utworzonym po wojnie państwie izraelskim protest ten stał się tradycją. Zakaz publicznego wykonywania, dotyczący przede wszystkim Israel Philharmonic Orchestra oraz państwowych stacji radiowych i telewizyjnych, obejmował nie tylko utwory Wagnera, ale również Carla Orffa i Richarda Straussa ${ }^{105}$. Mimo że to Orff i Strauss współpracowali z nazistami ${ }^{106}$, Wagner wzbudzał znacznie ostrzejsze kontrowersje. Orff i Strauss byli traktowani jako kompozytorzy, którzy jedynie ulegli wpływom nazistowskim, Wagner natomiast wydawał się złem większym, ponieważ jego poglądy przyczyniły się do powstania nazistowskiej ideologii ${ }^{107}$.

Publiczna debata, jaka wywiązywała się za każdym razem, kiedy zwolennicy twórczości Wagnera podejmowali próby przełamania zakazu, pokazuje, że o jego kształcie decyduje w znacznym stopniu tło polityczne, a nie immanentne cechy jego przedmiotu. Dyskusja, jaka toczy się w Izraelu wokół dzieł Wagnera, ma bowiem niewiele wspólnego z muzyką i wymową jego dzieł ${ }^{108}$. Jej największe nasilenie przypadło na okres, kiedy państwo izraelskie walczyło o swoją egzystencję i borykało się z problemem autodefinicji. W procesie wykształcania narodowej tożsamości z Wagnerem związane były dwie kwestie: pierwszą stanowiło pytanie o odpowiedni sposób kultywowania pamięci ofiar Holokaustu, drugą pytanie o to, jaki model kultury ma być podstawą nowo utworzonego państwa. Z pytaniem pierwszym wiązało się nie przekonanie o antysemickim charakterze jego oper, lecz postrzeganie Wagnera jako symbolu nazistowskiej kultury, wynikające głównie z intensywnej eksploatacji ideologicznej jego dzieł w okresie III Rzeszy. Pytanie drugie dostarczyło argumentów ortodoksyjnym i prawicowym ugrupowaniom, którym dzieła Wagnera były całkiem obce. Stronnictwa te wykorzystały jednak szansę wynikającą z faktu, że sprawa Wagnera dzieliła kręgi o świeckiej orientacji do pozyskania szerszego poparcia. W obydwu wypadkach dzieła Wagnera są nieobecne, a mimo to stosowane do celów pozamuzycznych i pozaliterackich.

Mechanizm ten widoczny jest np. w reakcjach na podjęte w latach 1952-1953 dwie próby przełamania zakazu. Ich intensywność wynika z ówczesnej sytuacji politycznej.

104 Por. N. Sheffi, Wagner in Israel. Vom Verbot bis zur Schaffung eines politischen Symbols 1938-1997, [w:] Richard Wagner und die Juden, s. 329.

${ }^{105}$ Najpierw złamany został zakaz wykonywania dzieł Ryszarda Straussa w marcu 1990, następnie zaczęto nadawać na koncertach publicznych oraz w publicznych stacjach radiowych i telewizyjnych utwory Orffa. (Por. ibidem, s. 342).

106 Por. ibidem, s. 329

107 N. Sheffi, Der Ring der Mythen. Die Wagner-Kontroverse in Israel, Göttingen 2002, s. 16.

108 Por. ibidem, s. 168. 


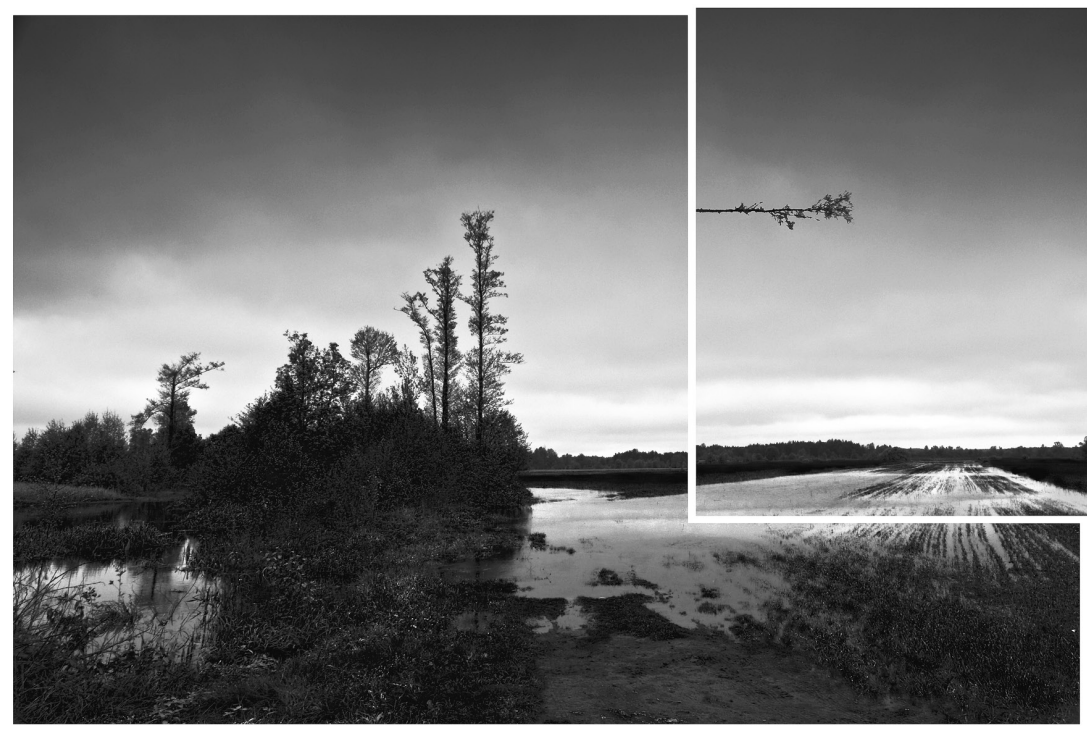

\section{Przestrzeń - 007}

W 1952 roku Ben Gurion przeforsował umowę pomiędzy Niemcami a Izraelem w sprawie odszkodowań dla żydowskich ofiar Holokaustu. W tym czasie każdy kontakt z Niemcami postrzegany był jako występek przeciw pamięci ofiar II wojny światowej ${ }^{109}$, projekt Ben $\mathrm{Gu}$ riona wywołał więc falę protestów, którym towarzyszyły bardzo silne emocje. Na czele protestujących stanął Menachem Begin, przewodniczący Herutu, poseł Knesetu i późniejszy premier. Obrady Knesetu w sprawie odszkodowań musiały zostać przerwane, ponieważ wzburzeni demonstranci rzucali przez okna kamienie. Mimo że Ben Gurion ostatecznie doprowadził do przyjęcia uchwały o odszkodowaniach, atmosfera publiczna nadal była bardzo napięta. Wystarczyła iskra, by wzniecić kolejne protesty. Taką iskrą stała się próba wykonania utworów Wagnera i Straussa przez Israel Philharmonic Orchestra, która nie została zrealizowana z powodu nacisków opinii publicznej, oraz wykonanie sonaty skrzyp-

109 Por. ibidem, s. 51. 
cowej Richarda Straussa przez Jashę Heifetza ${ }^{110}$, do którego doszło w 1953 roku w ramach tournée słynnego skrzypka z Israel Philharmonic Orchestra. Organizacje publiczne, jak np. Partisans Association, zwróciły się razem z członkami Knesetu reprezentującymi prawicowy Herut do ministra wychowania prof. Ben-Ziyona Dinura z apelem o zakończenie skandalu. Minister wystosował do Heifetza prośbę o rezygnację z wykonania utworu Straussa na pozostałych koncertach, Heifetz pozostał jednak nieugięty. Po jednym z koncertów został zaatakowany, napastnik uderzył go w ramię żelazną sztangą, narażając na szwank dalszą karierę skrzypka.

W 1981 roku Zubin Mehta, dyrygent IPO, wykonal jako dodatek po koncercie fragment z Tristana i Izoldy Richarda Wagnera. Wicepremier Dov Shilansky skrytykował Mehtę w wywiadzie radiowym jako tego, który „czytał o Auschwitz, podczas gdy nas tam prowadzono”"11 i zażądał powrotu Mehty do Indii. Prawicowa gazeta „Hamodiya” skomentowała inicjatywę Mehty w sposób jeszcze bardziej radykalny, akcentując rasistowski podtekst, jaki pojawił się w radiowej wypowiedzi Shilansky'ego: „IPO gra pod batutą importowanego z Indii dyrygenta" ${ }^{112}$. Ta nacjonalistyczna postawa zyskała poparcie w kręgach religijnych. Ortodoksyjne ugrupowania wykorzystały dyskusję wokół dzieł Wagnera do własnych celów. O ile trudno im było argumentować przeciw opinii publicznej, zgodnie uznającej zachodnie dziedzictwo kulturowe za jeden z koniecznych elementów wykształcenia, o tyle Wagner miał wielu przeciwników, był więc dogodnym celem do ataku. Furtka ta została wykorzystana: Wagner, który już i tak był negatywnym symbolem dla społeczeństwa, stał się kartą przetargową ortodoksyjnej mniejszości. W latach 90. w narodowo-ortodoksyjnej prasie powstaje obraz Wagnera jako symbolu wszystkich błędów zachodniej cywilizacji ${ }^{113}$.

Instrumentalizacja Wagnera, do której doszło w Izraelu, spowodowała, że z symbolu Holokaustu stał się on właściwie jego synonimem, jego nieodrodną częścią. Ukazuje ona ponadto, że zakaz stosowania dzieł Wagnera w Izraelu przypomina pod wieloma względami ich wykorzystywanie w okresie III Rzeszy. Chodzi o użycie (nie)obecnego na scenie dzieła do celów politycznych. Szczególnie uderzający jest fakt, że w izraelskiej dyskusji o Wagnerze $\mathrm{i}$ innych utożsamianych z nazistowskim reżimem kompozytorach pojawiły się rasistowskie akcenty (sprawa Mehty) oraz agresywne czyny (zamach na Heifetza). Wynika z tego, że radykalne obstawanie przy zakazie może stać się pożywką dla tych zjawisk, przeciw którym zakaz był skierowany: ekstremalnego nacjonalizmu i przemocy. Zakaz wystawiania dzieła może być zatem równie niebezpieczny jak jego upublicznianie.

110 Por. N. Sheffi, Wagner in Israel..., s. 330

111 Ibidem, s. 339.

112 Ibidem.

${ }^{113}$ Mimo to w latach 90. przestrzeganie zakazu stawało się coraz mniej rygorystyczne. Państwowe stacje radiowe zaczęły nadawać utwory Wagnera. W roku 1994 kablowy kanał kulturalno-naukowy przedstawił operę Holender Tułacz, a w roku 1998 emitował program z wybranymi operami Wagnera z różnych edycji festiwalu w Bayreuth, co nie wzbudziło sprzeciwu opinii publicznej. Por. Wagner in Israel, s. 344. 26 VII 2011 Izraelska Orkiestra Kameralna wykonała co prawda nie w Izraelu, ale w Bayreuth, pod batutą swojego obecnego dyrektora muzycznego, austriackiego dyrygenta Roberto Paternostro, poemat symfoniczny Siegfried-Idyll, co dla wielu Izraelczyków oznacza przełamanie zakazu. Roberto Paternostro ma izraelskie korzenie, wielu jego krewnych zostało zamordowanych przez hitlerowców, mimo to chętnie dyryguje utwory Wagnera. Na koncert przybyło do Bayreuth wielu słuchaczy z Izraela, po jego zakończeniu najpierw nastąpiła cisza, potem owacja na stojąco. Por. R. Siegel, A Tradition Shattered: Israelis Play Wagner At Bayreuth, http://www.npr.org (data dostępu: 05 XI 2011). 